\title{
Leaf Area Formation and Photosynthetic Activity of Sunflower Plants Depending on Fertilizers and Growth Regulators
}

\author{
Yevhenii Domaratskyi ${ }^{1 *}$ \\ 1 Kherson State Agrarian and Economic University, Stritenska St, 23, Kherson Oblast, 73006, Ukraine \\ Email: jdomar1981@gmail.com
}

\begin{abstract}
The study presents scientific substantiation and determination of the dependence of leaf area formation and photosynthetic activity of sunflower plants under the influence of fertilizers and growth regulators. The field research was conducted in 2015-2017 in the fields of the Voznesensk district in the Mykolaiv region, Ukraine (GPS: $47.630518,32.078974)$. The soil of the research field is common black soil with little humus accumulation and the content of hydrolyzed nitrogen $-1.5-1.8$; the content of highly absorbable phosphorous $-4.5-7.0$ and the content of exchangeable potassium $-12-15 \mathrm{mg} / 100 \mathrm{~g}$ of soil. The research was carried out by a two-factor scheme, where Factor A - the rate of mineral nutrition (the test plot without fertilizers; $\mathrm{N}_{30} \mathrm{P}_{45} ; \mathrm{N}_{60} \mathrm{P}_{90}$ ); and Factor $\mathrm{B}$ - foliar feeding with the Wuxal Microplant, Khelafit Combi and Fitomare preparations. The weather conditions in the years of the research were typical for this growing zone. It was established that the year 2017 was the least favorable with excessively low soil moisture and high temperature regime for growing the crop, and the weather conditions of 2015 and 2016 were the most favorable for cultivating sunflower. The research made it possible to determine that fertilizers combined with multifunctional preparations had a considerable impact on the leaf area and photosynthetic potential of agrocenosis. It proves that foliar feeding of sunflower plants at the stage of 6-8 true leaves with growth regulators contributed not only to a change in the total chlorophyll content, but also to its fractional composition. In all the cases there was a major increase in the content of the fraction "a". In particular, the maximal increase in this fraction was $90 \%$, whereas the difference did not exceed $76 \%$ in the fraction "b". Under nonfertilized conditions these indices were 48 and $13 \%$, respectively.
\end{abstract}

Keywords: sunflower, photosynthesis, photosynthetic potential, chlorophyll, fractional composition, assimilation surface.

\section{INTRODUCTION}

Leaf photosynthetic apparatus of plants plays a crucial role in the formation of productivity of all agrocenoses. This organ performs the function of photosynthesis and the formation of organic matter occurs in it. Many researchers determine optimal leaf area, emphasizing a negative impact of excessive leaf area development [Osmond 1981, Ciompi et al. 1996]. Sunflower plants develop quite large leaf area reaching 50-80 thousand $\mathrm{m}^{2} /$ ha [Ibrahim 2012]. However, sunflower plants maintain such leaf area indices within a short period of time, since the leaves of a lower tier cease their photosynthetic activity rapidly and their total area decreases [Wise et al. 1991].
The agricultural production in the South of Ukraine is not capable of ensuring the fullscale use of genetic potential of modern hybrids. Therefore, the actual sunflower productivity ranges from $30 \%$ to $50 \%$ of its genetic potential [Domaratskiy et al. 2018, Hussain et al. 2018]. A special role in the technological schemes of sunflower production is played by multi-functional combined preparations that, in addition to their growth stimulating characteristics, also have antifungal properties. They optimize plant nutrition and increase the coefficient of nutrient uptake by plants. Plant growth regulators serve as anti-stressors under extreme conditions of global and regional climate change [Domaratskiy et al. 2018, 2020]. 
Sunflower takes the first place among industrial crops by sown areas and is one of the most important oil crops in Ukraine and the EU countries. Its high value is explained by the fact that nearly all the plant parts are available for processing: the seeds produce high-quality oil and provide by-products used in livestock industry oilcake is a valuable concentrated feed with high protein content of up to 36\% [Laguna et al. 2018, Ngo et al. 2019]. Sunflower seed shells are a raw material for producing food and technical spirits, feed yeast and furfural, used in plastic production. Sunflower capitula can be used to feed livestock, and green mass can be ensilaged. Sunflower is also an excellent melliferous plant, and a considerable increase in the sown areas in Ukraine is explained by high economic indices of sunflower production [Unakitan et al. 2018].

However, an increase in sunflower productivity and in the level of production profitability is possible only due to implementation of new intensive technologies of sunflower production implying the application of appropriate doses and norms of mineral fertilizers, the use of plant growth stimulators and combined preparations, and also an integrated system of plant protection against pests and diseases [Spinelli et al. 2013, Hamzei et al. 2016, Akimowicz et al. 2021].

Well-developed, optimal in terms of volume and dynamics of functioning, photosynthetic apparatus is one of the factors for obtaining high and stable yields of agricultural crops. According to the scientists' experimental research [Dobrikova et al. 2015, Singh et al. 2019] the formation of dry matter of many agricultural crops, including sunflower, depends on the impact of natural and agro-technical factors. Different stages of plant development, genetic characteristics of variety and hybrid composition, specificity of weather and climate conditions and elements of technologies - all these have an impact on the content of dry matter in above-ground mass of sunflower that can vary greatly depending on these factors. It is very important to establish the impact of natural and agro-technical factors on the formation of leaf area, photosynthetic potential of agrocenosis and net productivity of photosynthesis [Talaat 2019].

Sunflower plants expend a large quantity of nutrients on yield formation, hybrids of intensive types are especially demanding. Depending on the growing conditions and genetic potential of a sunflower hybrid, the nutrient expenditures for the formation of a ton of seeds and a corresponding quantity of by-products are: nitrogen - 42-50 kg; phosphorous - 25-30 kg; potassium $-100-150 \mathrm{~kg}$. Foliar feeding of sunflower plants with microelements enhances the processes of assimilating macro-elements by sunflower plants, providing conditions for the formation of highly productive agrocenosis [ $\mathrm{Li}$ et al. 2018, Sahoo et al. 2018].

Plant growth stimulators are biologically active substances of natural origin that boost the intensity of exchange and growth processes in plants and, as a result, increase the productivity of agrocenoses of field crops and the quality of plant products. In low doses, these preparations have a positive impact on the accumulation of biomass, increasing the removal of biogenic elements from soil by stimulating the plant capability of assimilating macro- and micro-elements [Shanmugam et al. 2018, Domaratskyi et al. 2020, Wang et al. 2020].

In an organic system, fertilization with the levels of recirculation of mineral matter of 90 $95 \%, 70-80 \%$ of nitrogen and the maximum use of biological factors of plant growth stimulators, extend the volume of circulation of biogenic elements, in addition to an immediate increase in the productivity of agro-ecosystems. It contributes to a systematic growth in manufacturing organic products without additional expenses of resources of external origin. Therefore, plant growth stimulators are an important element of a farming system [Zhaoxiang et al. 2020].

The purpose of the study was to substantiate scientifically and establish the dependence of the formation of leaf area and photosynthetic activity of sunflower plants on fertilizers and growth regulators.

\section{MATERIALS AND METHODS}

The field research was conducted in 20152017 in the fields of the Voznesensk district in the Mykolaiv region, Ukraine (GPS: 47.630518, 32.078974). The soils of the research field are common black soils with little humus accumulation and the content of hydrolyzed nitrogen $1.5-1.8$; the content of highly absorbable phosphorous - 4.5-7.0 and the content of exchangeable potassium $-12-15 \mathrm{mg} / 100 \mathrm{~g}$ of soil.

The research was carried out by a two-factor scheme. Factor A was the rate of mineral 
nutrition (the test plot without fertilizers; $\mathrm{N}_{30} \mathrm{P}_{45}$; $\mathrm{N}_{60} \mathrm{P}_{90}$ ); and Factor $\mathrm{B}$ - foliar feeding with the Wuxal Microplant, Khelafit Combi and Fitomare preparations.

Wuxal Microplant is a complex suspension with high content of a wide range of microelements, also containing $\mathrm{Mg}, \mathrm{N}$ and $\mathrm{K}$ to prevent the imbalance in plant nutrition and increase the rate of photosynthesis.

Khelafit Combi is a multifunctional preparation that contains a complex of highly absorbable microelements in a chelate form balanced for all the stages of crop growth ( $\mathrm{Fe}, \mathrm{Mg}, \mathrm{Mn}, \mathrm{Mo}, \mathrm{Cu}$, $\mathrm{B})$, spores and cells of a microbial culture - the producers of the Bacillus Subtilus and Pseudomonas genera that provide the preparation with fungicidal effect to fight fungal and bacterial diseases, as well as multifunctional growth stimulators and regulators (auxins, cytokines, gibberellins, betaine, humic and fulvic acids, amino acids).

Fitomare is a liquid fertilizer and bio-stimulator based on the extract of the Ascophyllum nodosum seaweeds, obtained by means of an exclusive technology of the "Atlantica Agricola" company). Winter wheat was a previous crop for sunflower.

Mineral fertilizers were applied with basic soil tillage by the method of surface broadcast. The sunflower plants were treated with an aboveground sprinkler at the stage of 6-8 true leaves. The area of the research plot was $280 \mathrm{~m}^{2}$, and that of the observation plot $-112 \mathrm{~m}^{2}$. The experiment included four replications.

The leaf samples to determine chlorophyll content were taken at the stage of blooming. The leaf stalks were removed, large ribs were cut out, the mass was chopped with a knife; some samples were taken to measure leaf moisture content and the remaining mass was covered with ethyl alcohol. After complete extraction of chlorophyll, the light transmission of the suspension was measured using the photoelectric colorimeter FEC56. The data of the photoelectric colorimeter were used in the graph with a grading curve where certain chlorophyll content corresponds to any value of optical density. In order to determine fractional composition, the measurement was performed with two wavelengths (540 and $650 \mathrm{~nm}$ ). The obtained results were calculated per ton of dry weight by the formula:

$$
X_{\text {avg }}=\left(X_{w w} \cdot 100\right) /(100-W) \text {; }
$$

where: $X_{\text {avg }}$ - chlorophyll content per dry weight, $\mathrm{mg} / \mathrm{g}$
$X_{w w}-$ chlorophyll content per wet weight, $\mathrm{mg} / \mathrm{g}$

$W$ - actual leaf moisture, $\%$

Yield registration was performed with the method of combine threshing from the area of the observation plot. In fact, the data on the obtained yield were considered in terms of basic moisture (8\%) taking into account the admixtures.

\section{RESULTS AND DISCUSSION}

The main limiting factor for realization of the potential productivity of hybrids under the conditions of the Southern Steppe of Ukraine is moisture deficit. The weather conditions in the years of the research (2015-2017) can be considered as semi-arid and typical for this growing zone.

The analysis of the weather conditions in the years of the research, based on the air temperature and the amount of precipitation in the growing season of sunflower plants, showed that the year 2017 was the least favorable with extremely low soil moisture content and high temperature regime for growing the crop. The weather conditions of 2015 and 2016 were more favorable for sunflower cultivation. These years were characterized by a higher amount of precipitation in the crop growing season against the background of the increased average monthly temperature regime in comparison with the average multi-year indices (Fig. 1, 2).

The program of the scientific research involved dynamic measurement of leaf area at different stages of plant development. The yield of dry aboveground biomass was determined, whereas photosynthetic potential $(\mathrm{PhP})$ and the net productivity of photosynthesis $(\mathrm{NPPh})$ were calculated on the basis of these data by the formulae:

$$
\begin{gathered}
\mathrm{PhP}=S_{\text {avg }} \cdot T ; \\
\mathrm{NPPh}=\left(Y_{2}-Y_{1}\right) / \mathrm{PhP} ;
\end{gathered}
$$

where: $S_{\text {avg }}$ - average leaf area in the analysis period;

$T$ - duration of the period;

$Y_{1}$ - productivity of dry biomass at the beginning period;

$Y_{2}$ - productivity of dry biomass at the end of the period.

Generalized data on these calculations in the years of the research are given in Table 1. 
When conducting quantitative evaluation of the efficiency of fertilizers and preparations, it was determined that both factors have a noticeable effect on the leaf area photosynthetic potential of agrocenosis. The latter increases not only due to the leaf area, but also owing to prolongation of its activity. The duration of the period between the beginning of capitulum formation and blooming in the test variant was 33 days on average, and it was 5 days more in the variant with the nutrition $\left(\mathrm{N}_{60} \mathrm{P}_{90}\right)$ and the application of the Khelafit Combi preparation. Therefore, if $\mathrm{PhP}$ in this variant depended only on the average leaf area, this index was not 1224 , but 1063 thous $\cdot \mathrm{m}^{2} / \mathrm{ha}^{*}$ days, i.e. $15 \%$ less. Thus, an increasing direct effect of fertilizers and preparations due to prolongation of the period was established.

There is an inverse correlation with regard to the qualitative index - NPPh, the application of fertilizers and preparations caused a decline in its value. The average level of NPPh without fertilizers was $3.09 \mathrm{~g} / \mathrm{m}^{2}$ per day, it fell by $8.1 \%$ with the use of $\mathrm{N}_{30} \mathrm{P}_{45}$, and by $10.1 \%$ - with the use of
$\mathrm{N}_{60} \mathrm{P}_{90}$. It proves that an increase in the aboveground biomass is a result of extensive process due to the growth of assimilation surface. Therefore, it is necessary to continue searching for the ways to affect the rate of photosynthesis.

The results of the data analysis of the field research on the intensity of ceasing photosynthetic activity of leaf area allowed determining a clear tendency to prolongation of the activity of assimilation surface due to the application of multifunctional preparations. These data are given in Table 2.

The sunflower plants in the test variant had no green leaves at the beginning of September on average in the years of the research, whereas complete cessation of leaf photosynthetic activity with the application of the multifunctional preparation Khelafit Combi was registered 10 days later, in comparison with the test variant.

There were certain differences in the years of the research, but under any conditions, multifunctional preparations had a tendency to prolong the activity of assimilation apparatus that results

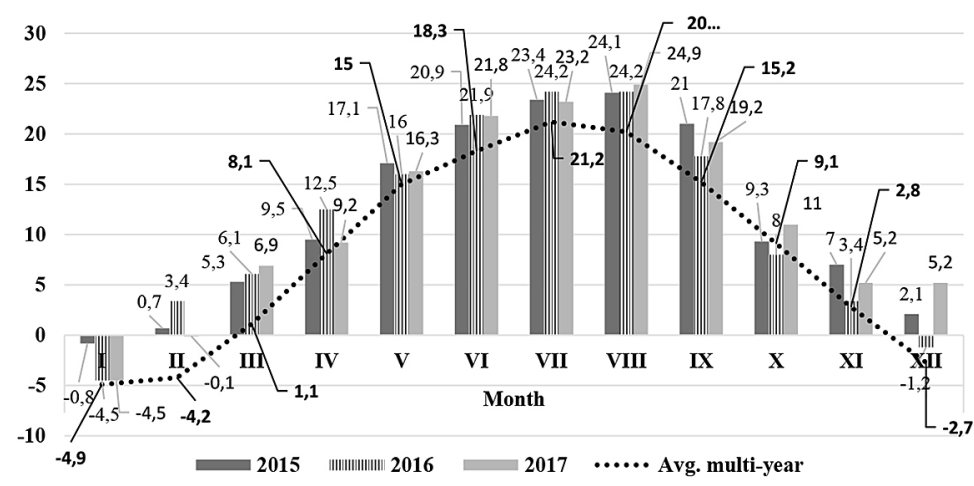

Fig. 1. The average monthly air temperature in the years of the research in comparison with the average multi-year indices, ${ }^{\circ} \mathrm{C}$

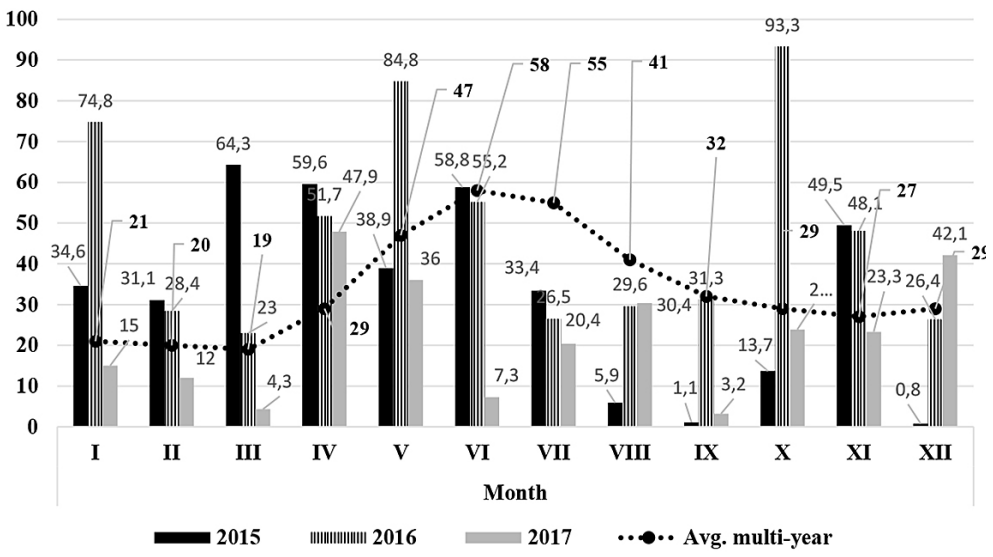

Fig. 2. The amount of precipitation in the years of the research in comparison with the average multi-year indices, $\mathrm{mm}$ 
Table 1. The main indices of photosynthetic activity of sunflower plants in the period between the stages of capitulum formation - blooming, the average in 2015-2017

\begin{tabular}{|c|c|c|c|c|c|c|c|c|}
\hline \multirow[b]{2}{*}{$\begin{array}{l}\text { Rates of } \\
\text { nutrition }\end{array}$} & \multirow[b]{2}{*}{ Preparation } & \multicolumn{3}{|c|}{ Leaf area, thous. $\mathrm{m}^{2} / \mathrm{ha}$} & \multirow{2}{*}{$\begin{array}{l}\text { The } \\
\text { duration } \\
\text { of the } \\
\text { period, } \\
\text { days }\end{array}$} & \multirow[b]{2}{*}{$\begin{array}{c}\text { Photosynthetic } \\
\text { potential, thous. } \\
\mathrm{m}^{2} / \mathrm{ha}^{*} \text { days }\end{array}$} & \multirow{2}{*}{$\begin{array}{l}\text { Increase } \\
\text { in dry } \\
\text { aboveg- } \\
\text { round } \\
\text { mass, t/ha }\end{array}$} & \multirow[b]{2}{*}{$\begin{array}{l}\text { Net productiv- } \\
\text { ity of photo- } \\
\text { synthesis, } \\
\mathrm{g} / \mathrm{m}^{2} \text { per day }\end{array}$} \\
\hline & & $\begin{array}{l}\text { The } \\
\text { beginning } \\
\text { of the } \\
\text { period }\end{array}$ & $\begin{array}{l}\text { The end } \\
\text { of the } \\
\text { period }\end{array}$ & $\begin{array}{c}\text { The } \\
\text { average }\end{array}$ & & & & \\
\hline \multirow{4}{*}{$\begin{array}{l}\text { Without } \\
\text { fertilizers }\end{array}$} & $\begin{array}{l}\text { Without preparations } \\
\text { (pure water) }\end{array}$ & 21.2 & 33.1 & 27.2 & 33 & 898 & 2.81 & 3.13 \\
\hline & Wuxal & 23.0 & 34.8 & 28.9 & 33 & 954 & 2.94 & 3.08 \\
\hline & Fitomare & 22.1 & 34.8 & 28.0 & 35 & 980 & 3.01 & 3.07 \\
\hline & Khelafit Kombi & 23.4 & 35.5 & 30.0 & 34 & 1020 & 3.12 & 3.06 \\
\hline \multirow{4}{*}{$\mathrm{N}_{30} \mathrm{P}_{45}$} & Without pure water) & 22.8 & 34.1 & 28.5 & 36 & 1026 & 2.98 & 2.90 \\
\hline & Wuxal & 24.0 & 35.3 & 29.7 & 36 & 1069 & 3.09 & 2.89 \\
\hline & Fitomare & 24.0 & 36.0 & 30.0 & 37 & 1110 & 3.13 & 2.82 \\
\hline & Khelafit Kombi & 24.9 & 37.0 & 32.0 & 37 & 1184 & 3.25 & 2.74 \\
\hline \multirow{3}{*}{$\mathrm{N}_{60} \mathrm{P}_{90}$} & $\begin{array}{l}\text { Without preparations } \\
\text { (pure water) }\end{array}$ & 24,0 & 34.0 & 29.0 & 37 & 1073 & 3.07 & 2.86 \\
\hline & Wuxal & 25.0 & 37.0 & 31.0 & 37 & 1147 & 3.15 & 2.75 \\
\hline & Fitomare & 25.0 & 37.0 & 31.0 & 38 & 1178 & 3.15 & 2.67 \\
\hline
\end{tabular}

in slowing down the cessation of photosynthetic activity of leaf photosynthetic apparatus.

Photosynthesis is a unique process of generating organic matter due to the sun energy and biochemical reactions in plants. The latter are known to occur provided that there is green pigment chlorophyll. Chlorophyll has porphyrin structure, that is similar to blood heme, though heme has a ferrous $(\mathrm{Fe})$ complex, and chlorophyll has a magnesium $(\mathrm{Mg})$ complex.

It is known that chlorophyll of "a"-fraction is necessary for most photosynthetic organisms to transform the light energy into chemical energy, performing the function of a conductor of oxygenic photosynthesis. This chlorophyll absorbs light most actively in the violet-blue and orangered parts of the spectrum. All organisms with an oxygenic type of photosynthesis use chlorophyll "a" [Pemmaraju et al. 2018].
Chlorophyll "a" absorbs light in violet, blue and red parts of the spectrum, and the green color, on the contrary, reflects it. Its spectrum of absorption expends due to accessory pigments - chlorophyll of "b"-fraction. Under the conditions of insufficient light intensity, there is an increase in the ratio of chlorophyll of "b"-fraction to chlorophyll of "a"-fraction, synthesizing more molecules of the first type than those of the second type, increasing the rate of photosynthesis [Kumar et al. 2020].

Chlorophyll of "b"-fraction is an accessory pigment absorbing light more in a blue part of the spectrum; therefore, it is yellow and green. This fraction is responsible for maintaining photosynthesis intensity under the conditions of insufficient light [Babadi et al. 2020]. The content of " $\mathrm{b}$ "-chlorophyll in higher plants and algae is about $1 / 3$ of the content of "a"-chlorophyll. It normally increases when plants adapt to insufficient light,

Table 2. The dynamics of the cessation of photosynthetic activity of leaf photosynthetic apparatus at the stage of seed development depending on the preparations, the average in 2015-2017

\begin{tabular}{|l|c|c|c|c|c|}
\hline \multirow{3}{*}{ Month } & \multirow{2}{*}{ Date } & \multicolumn{4}{|c|}{ Remaining green leaves, \% out of the maximal level } \\
\cline { 2 - 6 } & & Test variant & Wuxal & Fitomare & Khelafit Combi \\
\hline \multirow{4}{*}{ August } & 10 & 18.4 & 19.2 & 20.4 & 20.1 \\
\cline { 2 - 6 } & 15 & 15.0 & 17.0 & 17.5 & 18.4 \\
\cline { 2 - 6 } & 20 & 11.5 & 14.1 & 13.8 & 15.6 \\
\cline { 2 - 6 } & 25 & 7.6 & 10.4 & 11.0 & 9.1 \\
\cline { 2 - 6 } & 30 & 3.9 & 6,1 & 7.0 & 6.6 \\
\hline \multirow{3}{*}{ September } & 05 & 0 & 2.2 & 3.8 & 2.8 \\
\cline { 2 - 6 } & 10 & 0 & 0 & 0 & 0 \\
\hline
\end{tabular}


Table 3. Chlorophyll content in sunflower leaves at the stage of blooming, the average in 2015-2017

\begin{tabular}{|c|c|c|c|c|c|}
\hline \multirow{3}{*}{ Rate of nutrition } & \multirow{3}{*}{ Preparation } & \multicolumn{3}{|c|}{$\begin{array}{l}\text { Chlorophyll content, } \\
\mathrm{mg} / \mathrm{g} \text { of dry matter }\end{array}$} & \multirow{3}{*}{$\begin{array}{l}\text { Ratio of the fractior } \\
\text { "a" to "b" }\end{array}$} \\
\hline & & \multirow{2}{*}{ total } & \multicolumn{2}{|c|}{ fraction } & \\
\hline & & & "a" & "b" & \\
\hline \multirow{4}{*}{ Without fertilizers } & Without preparations (pure water) & 5.18 & 3.60 & 1.59 & 2.26 \\
\hline & Wuxal & 6.29 & 4.58 & 1.71 & 2.67 \\
\hline & Fitomare & 7.07 & 5.27 & 1,80 & 2.93 \\
\hline & Khelafit Combi & 7.03 & 5.34 & 1.69 & 3.16 \\
\hline \multirow{4}{*}{$\mathrm{N}_{30} \mathrm{P}_{45}$} & Without preparations pure water) & 7.36 & 5.60 & 1.76 & 3.18 \\
\hline & Wuxal & 8.63 & 6.83 & 1.80 & 3.79 \\
\hline & Fitomare & 8.94 & 7.02 & 1.91 & 3.68 \\
\hline & Khelafit Combi & 8.32 & 6.66 & 1.66 & 4.01 \\
\hline \multirow{4}{*}{$\mathrm{N}_{60} \mathrm{P}_{90}$} & Without preparations (pure water) & 7.50 & 5.69 & 1.81 & 3.16 \\
\hline & Wuxal & 8.81 & 6.12 & 2.69 & 2.28 \\
\hline & Fitomare & 8.97 & 6.17 & 2.80 & 2.20 \\
\hline & Khelafit Combi & 8.44 & 6.05 & 2.39 & 2.53 \\
\hline
\end{tabular}

expanding the range of wavelengths, absorbed by chloroplasts, adapted to insufficient light [Büchel et al. 2020].

The research program involved determination of the fractional composition of plant green pigment - chlorophyll, that is vital for photosynthetic processes in agrocenosis (Table 3 ).

The research results show that the chlorophyll content increased considerably under the influence of fertilizers and preparations, the maximal value of this index was in the variant with the application of the Fitomare preparation with the rate of nutrition of $\mathrm{N}_{60} \mathrm{P}_{90}-8.97 \mathrm{mg} / \mathrm{g}$ of dry matter, that is $73 \%$ more than in the test variant (without fertilizers and preparations).

\section{CONCLUSIONS}

Fertilizers combined with multi-functional preparations had an essential impact on leaf area and photosynthetic potential of agrocenosis. The latter increases not only due to leaf area, but also owing to the prolongation of its activity.

The results of the generalized data of the field research allowed establishing that foliar feeding of sunflower plants at the stage of 6-8 true leaves with plant growth regulators contributed to changes not only in the total chlorophyll content, but also in its fractional composition. In all the cases, there was a major increase in the content of "a"-fraction. The maximal increase in this fraction was $90 \%$, whereas the difference did not exceed $76 \%$ in "b"-fraction. Under non-irrigated conditions, these indices were $48 \%$ and $13 \%$ respectively. It means that optimal selection of a combined multi-functional preparation can be an efficient method for regulating chlorophyll content and its fractional composition.

\section{REFERENCES}

1. Osmond C.B. 1981. Photorespiration and photoinhibition: Some implications for the energetics of photosynthesis. Biochimica et Biophysica Acta (BBA)-Reviews on Bioenergetics, 639(2), 77-98.

2. Ciompi S., Gentili E., Guidi L., Soldatini G.F. 1996. The effect of nitrogen deficiency on leaf gas exchange and chlorophyll fluorescence parameters in sunflower. Plant Science, 118(2), 177-184.

3. Ibrahim H.M. 2012. Response of Some Sunflower Hybrids to Different Levels of Plant Density. APCBEE Procedia, 4, 175-182.

4. Wise R.R., Sparrow D.H., Ortiz-Lopez A., Ort D.R. 1991. Biochemical regulation during the mid-day decline of photosynthesis in field-grown sunflower. Plant Science, 74(1), 45-52.

5. Domaratskiy E.O., Bazaliy V.V., Domaratskiy O.O., Dobrovol'skiy A.V., Kyrychenko N.V., Kozlova O.P. 2018. Influence of Mineral Nutrition and Combined Growth Regulating Chemical on Nutrient Status of Sunflower. Indian Journal of Ecology, 45(1), 126-129.

6. Domaratskiy E.O., Zhuykov O.G., Ivaniv M.O. 2018. Influence of Sowing Periods and Seeding Rates on Yield of Grain Sorghum Hybrids under Regional Climatic Transformations. Indian Journal of Ecology, 45(4), 785-789.

7. Domaratskiy Ye., Kozlova O., Kaplina A. 2020. Economic Efficiency of Applying Environmentally 
Friendly Fertilizers in Production Technologies in the South of Ukraine. Indian Journal of Ecology, 47(3), 624-629.

8. Hussain M., Faroog Sh., Hasan W., Ul-Allah S., Tanveer M., Faroog M., Nawaz A. 2018. Drought stress in sunflower: Physiological effects and its management through breeding and agronomic alternatives. Agricultural Water Management, 201, 152-166.

9. Unakitan G., Aydin B. 2018. A comparison of energy use efficiency and economic analysis of wheat and sunflower production in Turkey: A case study in Thrace Region. Energy, 149, 279-285.

10. Ngo H., Latona R., Sarker M.I., Yee W., Hums M., Moreau R.A. 2019. A process to convert sunflower oil into a value added branched chain oil with unique properties. Industrial Crops and Products, 139, 111457.

11. Laguna O., Barakat A., Alhamada H., Durand E., Barea B., Fine F., Villeneuve P., Citeau M., Dauguet S., Lecomte G. 2018. Production of proteins and phenolic compounds enriched fractions from rapeseed and sunflower meals by dry fractionation processes. Industrial Crops and Products, 118, 160-172.

12. Akimowicz M., Corso J.P.D., Gallai N., Kephaliacos C. 2021. Adopt to adapt? Farmers' varietal innovation adoption in a context of climate change. The case of sunflower hybrids in France. Journal of Cleaner Production, 279, 123654.

13. Spinelli D., Bardi L., Fierro A., Jez S., Basosi R. 2013. Environmental analysis of sunflower production with different forms of mineral nitrogen fertilizers. Journal of Environmental Management, 129, 302-308.

14. Hamzei J., Seyyedi M. 2016. Energy use and inputoutput costs for sunflower production in sole and intercropping with soybean under different tillage systems. Soil and Tillage Research, 157, 73-82.

15. Singh R., Upadhyay A.K., Singh D.V., Singh J.S., Singh D.P. 2019. Photosynthetic performance, nutrient status and lipid yield of microalgae Chlorella vulgaris and Chlorococcum humicola under UV-B exposure. Current Research in Biotechnology, 1, 65-77.

16. Dobrikova A.G., Apostolova E.L. 2015. Damage and protection of the photosynthetic apparatus from UV-B radiation. II. Effect of quercetin at different pH. Journal of Plant Physiology, 184, 98-105.

17. Talaat N.B. 2019. Effective microorganisms: An innovative tool for inducing common bean (Phaseolus vulgaris L.) salt-tolerance by regulating photosynthetic rate and endogenous phytohormones production. Scientia Horticulturae, 250, 254-265.

18. Li S., Duan Y., Guo T., Zhang P., He P., Majumbar K. 2018. Sunflower response to potassium fertilization and nutrient requirement estimation. Journal of Integrative Agriculture, 17(12), 2802-2812.

19. Sahoo P., Brar A.S., Sharma S. 2018. Effect of methods of irrigation and sulphur nutrition on seed yield, economic and bio-physical water productivity of two sunflower (Helianthus annuus L.) hybrids. Agricultural Water Management, 206, 158-164.

20. Domaratskyi Ye., Kozlova O., Domaratskyi O., Lavrynenko Iu., Bazaliy V. 2020. Effect of nitrogen nutrition and environmentally friendly combined chemicals on productivity of winter rapeseed under global climate change. Indian Journal of Ecology, 47(2), 330-336.

21. Wang J.Y., Lin P.Y., Al-Babili S. 2020. On the biosynthesis and evolution of apocarotenoid plant growth regulators. Seminars in Cell \& Developmental Biology, 109, 3-11.

22. Shanmugam M., Seth A. 2018. Recovery ratio and quality of an agricultural bio-stimulant and semirefined carrageenan co-produced from the fresh biomass of Kappaphycus alvarezii with respect to seasonality. Algal Research, 32, 362-371.

23. Zhaoxiang W., Huihu L., Qiaoli L., Changyan Y., Faxin Y. 2020. Application of bio-organic fertilizer, not biochar, in degraded red soil improves soil nutrients and plant growth. Rhizosphere, 16, 100264.

24. Pemmaradju D., Appidi T., Minhas G., Singh S.P., Khan N., Pal M., Srivastava R., Rengan A.K. 2018. Chlorophyll rich biomolecular fraction of A. cadamba loaded into polymeric nanosystem coupled with Photothermal Therapy: A synergistic approach for cancer theranostics. International Journal of Biological Macromolecules, 110, 383-391.

25. Kumar D., Singh H., Raj S., Soni V. 2020. Chlorophyll a fluorescence kinetics of mung bean (Vigna radiata L.) grown under artificial continuous light. Biochemistry and Biophysics Reports, 24, 100813.

26. Babadi F.E., Boonnoun P., Nootong K., Powtongsook S., Goto M., Shotipruk A. 2020. Identification of carotenoids and chlorophylls from green algae Chlorococcum humicola and extraction by liquefied dimethyl ether. Food and Bioproducts Processing, 123, 296-303.

27. Büchel C. 2020. Light harvesting complexes in chlorophyll c-containing algae. Biochimica et Biophysica Acta (BBA)-Bioenergetics, 1861(4), 148027. 